\title{
E-Learning Bebasis Wordpress Sebagai Alternatif Media Pembelajaran
}

\section{Fahmi Achta Pratama1*, Hansi Effendi2}

1,2 Program Magister Pendidikan Teknologi dan Kejuruan, Universitas Negeri Padang, Padang, Indonesia

\section{ART ICLE INFO}

\section{Article history:}

Received September 06, 2021

Revised September 08, 2021

Accepted October 14, 2021

Available online October 25, 2021

Kata Kunci:

E-Learning, Wordpress, Media

Pembelajaran

Keywords:

E-Learning, Wordpress, Learning Media

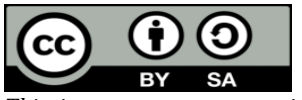

This is an open access article under the CC BY-SA license.

Copyright (C) 2021 by Author.

Published by Universitas Pendidikan Ganesha.

\section{A B S T R A C T}

Obstacles faced by lecturers and students in programming language learning when using e-learning. E-learning often has errors when accessed, especially during peak hours. The purpose of this research is to design WordPress-based e-learning as an alternative programming language learning media, then test it and analyze the level of validity, practicality and effectiveness. This type of research is the development of the Borg and Gall model. This research design includes potential problems, information gathering, product design, design validation, design improvement, limited trials, product revisions, usage trials, product revisions, and final products. The subjects of this study were two validators of learning media experts, two experts on programming language materials. The test subjects were 2 Programming Language lecturers, five students were tested in a limited way, and 30 students were tried out for use. Methods of data collection using observation, interviews, and questionnaires. This research instrument is a validation questionnaire of media experts and material experts, practicality questionnaires on limited trials and trials of use, and student learning outcomes. Quantitative methods analyzed data. The results of this study are the validation of media experts with a value of 0.902 (valid), material experts with a value of 0.842 (valid). In limited trials, WordPress-based e-learning got a score of $80 \%$ (practical) from students and got a score of $88.75 \%$ (practical) from lecturers; 82.83\% (practically) of the student's value in the trial use; For the effectiveness trial, 86.67\% of students got a score of 70 (classical effectiveness). Moreover, in terms of the Gain Score, it gets 54.25\% (medium). So, WordPress-based e-learning is feasible, practical and effective as an alternative programming language learning media.

\section{PENDAHULUAN}

Pembelajaran dan perkembangan teknologi adalah dua hal yang tidak bisa dipisahakan. Salah satu peran teknologi dalam proses pembelajaran saat ini adalah pembelajaran daring. Pembelajaran daring adalah sistem pembelajaran dimana pendidik dan peserta didik tidak memiliki kontak langsung, tetapi pertemuan dilakukan secara online melalui jaringan internet(Azizah, 2020; Karollina et al., 2021). Pembelajaran online membutuhkan kreativitas dan keterampilan pendidik, seperti memilih media pembelajaran berbasis teknologi yang akan digunakan (Sakiah \& Effendi, 2021). Pembelajaran online atau 
e-learning yang diakses menggunakan web merupakan salah satu sarana pembelajaran yang dikenal dengan istilah learning management system "LMS" (Santosa et al., 2020). Salah satu produk dari inovasi teknologi yang digunakan adalah e-learning. E-learning merupakan inovasi pembelajaran dan solusi alternatif untuk mengembangkan kebutuhan pembelajaran (Bani Hani et al., 2021; Prasetya, 2015). Elearning berarti pembelajaran menggunakan layanan pendukung perangkat elektronik (Elyas, 2018). Pembelajaran dengan pemanfaatan e-learning dalam pembelajaran akan mempermudah pendidik untuk mengajar dan peserta didik untuk belajar, sehingga pembelajaran dapat dilakukan dimana saja dan kapan saja, karena pembelajaran yang berada dikelas (secara konvensional) dipindahkan kedalam sebuah jaringan internet, sehingga pembelajaran dapat diakses melalui gadget, smartphone, komputer atau bahkan laptop (Abdulmajid et al., 2017; Budi et al., 2019; Salsabila et al., 2020; Ningsih \& Erdisna, 2021; Ratnawati et al., 2019; Sari \& Priatna, 2020). Salah satu Universitas yang menggunakan e e-learning adalah Universitas Negeri Padang (UNP).

Universitas Negeri Padang (UNP) sebagai satu diantara Perguruan Tinggi Negeri di Indonesia dalam menciptakan lulusannya yang unggul mempunyai salah satu mata kuliah Bahasa Pemprograman yang ditujukan kepada mahasiswa (UNP, 2018). Secara struktural pembelajaran Bahasa Pemprograman terdapat di Jurusan Teknik Elektro pada semester ganjil yang diberi nama dengan mata kuliah Algoritma dan Pemrograman/ Bahasa Pemprograman. Kemudian, untuk mahasiswa secara umum juga terdapat pembelajaran Bahasa Pemprograman tiap semesternya. Nama mata kuliahnya Pengantar Coding yang berada dibawah Mata Kuliah Umum (MKU) Universitas. Pada pembelajaran Bahasa Pemprograman, pembelajarannya memakai sistem E-Learning dengan perangkat lunak media Moodle. Namun berdasarkan hasil wawancara yang dilaksanakan terhadap 3 orang dosen pengampu Bahasa Pemprograman dan 2 orang mahasiswa yang mengambil mata kuliah Bahasa Pemprograman di UNP, pembelajaran yang menggunakan e-learning tersebut terdapat persoalan-persoalan yang dihadapi, seperti e-learning UNP yang seringkali error ketika diakses, apalagi pada jam-jam sibuk. Kemudian, juga di dapatkan data yang berasal dari Unit Kegiatan Wadah Pengkajian dan Pengembangan Sosial Politik (UK-WP2SOSPOL) UNP. Data tersebut berupa hasil survei yang dilakukan oleh UK-WP2SOSPOL UNP terhadap 1070 responden mahasiswa terkait pelaksanaan pembelajaran menggunakan e-learning di UNP pada 3 Januari 2021 lalu, dari hasil survei tersebut diketahui 325 orang mahasiswa UNP menyampaikan keluhannya terkait $e$ learning yang seringkali mengalami error ketika diakses.

Sehingga dari permasalahan-permasalahan ini perlu beberapa alternatif media pembelajaran yang dapat mengurangi dampak tersebut. Dalam penelitian terdahulu yang dilakukan (Sianturi \& Lisum, 2018; A. Widodo \& Nursaptini, 2020) menemukan permasalahan-permasalahan yang terdapat pada $e$ learning membutuhkan media e-learning alternatif untuk mengatasi kendala-kendala yang ada. Sehingga e-learning alternatif yang dibuat sebaiknya praktis dan mudah digunakan dalam pembelajaran.Berdasarkan pemaparan yang sudah peneliti jelaskan, maka disini peneliti menganalisis antara manfaat e-learning dengan kondisi yang ada di UNP berdasarkan hasil observasi. Disini peneliti melakukan evaluasi dengan model kesenjangan atau discrepancy. Dari evaluasi ini akan didapat kesenjangan yang terjadi antara harapan dan kenyataan. Evaluasi model kesenjangan atau discrepancy adalah menganalisis kondisi seharusnya/ tujuan yang diharapkan dengan kondisi yang sebenarnya terjadi (Widyastuti, 2017; Saputra, 2019). Maka, dalam penelitian ini yang menjadi tujuan kondisi seharusnya adalah e-learning mempermudah mahasiswa dan dosen dalam pembelajaran, hanya saja kondisi saat pembelajaran di UNP, khususnya mata kuliah Bahasa Pemprograman ditemukan e-learning tersebut susah diakses dan juga sering error. Ketidaksesuaian fungsi e-learning di UNP inilah yang menjadi persoalan dalam penelitian ini. Berangkat dari penjelasan-penjelasan yang sudah peneliti paparkan, maka dibutuhkan e-learning yang menjadi alternatif media pembelajaran pada mata kuliah Bahasa Pemprograman di UNP, e-learning tersebut dibuat berbasis wordpress. Karena e-learning ini mudah diakses, simpel desainnya, dan praktis digunakan dalam pembelajaran. Wordpress penggunaanya mudah dan ringan diakses (Muliono, 2016; Zulkarnain et al., 2020). Pernyataan ini sesuai dengan hasil penelitian yang sudah dilakukan.

Penelitian yang menyatakan bahwa media e-learning layak digunakan dalam pembelajaran, mendapat respon yang bagus dari pendidik dan peserta didik sebagai pengguna e-learning dan efektif dalam pembelajaran, dalam penelitian tersebut, e-learning yang dikembangkan dibuat simpel dan mudah digunakan oleh peneliti, sehingga tidak ada kendala dihadapi dosen dan mahasiswa ketika mengaksesnya (Radhiani \& Sirwan, 2019; Rijal \& Sofiarini, 2019; Widodo \& Hidayah, 2020; Saluky, 2016; Weni \& Isnani, 2016; Anggrasari, 2020; Dalu \& Rohman, 2019; Muharto et al, 2017; Ihsan et al, 2019; Lilis et al, 2020; Khusniyah, 2020). Penelitian berbeda dengan penelitian-penelitian sebelumnya adalah e-learning berbasis wordpress bisa dipakai sebagai alternatif media oleh dosen dan mahasiswa. Media e-learning yang dipakai nantinya dibuat dalam bentuk website dengan platform wordpress dengan desain yang sangat simpel dan dibuat ringan ketika diakses, didalamnya terdapat bahan ajar, forum diskusi, presensi 
mahasiswa, ujian-ujian serta latihan, dan juga dilengkapi dengan video tutorial. Dengan demikian, proses belajar mengajar pada Bahasa Pemprograman dapat terlaksana dengan baik. Kemudian, penelitian ini penting untuk dilakukan, karena urgensinya adalah untuk mengatasi permasalahan-permasalahan yang dihadapi pada pembelajaran Bahasa Pemprograman, hal ini juga sudah peneliti kuatkan sebelumnya. Penelitian ini bertujuan untuk merancang e-learning berbasis wordpress sebagai alternatif media pembelajaran pada mata kuliah Bahasa Pemprograman di UNP, Melakukan validasi oleh para ahli untuk menentukan kelayakan dari e-learning yang dikembangkan dan menguji coba e-learning tersebut agar dianalisis untuk mengetahui tingkat kepraktisan dan keefektifannya.

\section{METODE}

Riset ini adalah penelitian pengembangan. Penelitian pengembangan yang dilakukan ialah penelitian yang dijelaskan oleh Borg and Gall dalam (Sugiyono, 2016), sehingga tahapan penelitiannya adalah: (1) menentukan potensi masalah, (2) melakukan pengumpulan informasi, (3) membuat produk, (4) memvalidasi desain, (5) memperbaiki desain, (6) uji coba terbatas, (7) revisi produk, (8) uji coba pemakaian, (9) revisi produk, (10) produk final. Subjek dalam penelitian ini adalah 2 orang validator ahli media pembelajaran, 2 orang ahli materi Bahasa Pemprograman. Dan subjek uji coba pada penelitian ini adalah 2 orang dosen Bahasa Pemprograman, 5 orang mahasiswa diuji coba terbatas dan 30 orang mahasiswa diuji coba pemakaian. Kemudian, teknik pengumpulan data penelitian ini yang dilakukan menggunakan wawancara terhadap dosen dan mahasiswa Bahasa Pemprograman serta menyebarkan instrumen validasi berupa angket kepada para validator dan instrumen kepraktisan yang berupa angket kepada responden yang diantaranya dosen dan mahasiswa serta menyebarkan instrumen keefektifan yang berupa soal objektif untuk uji efektivitas kepada mahasiswa. Untuk mengukur kelayakan dari instrumen validitas dan kepraktisan oleh ahli instrumen. Validitas yang digunakan dalam penelitian ini adalah validitas isi. (Gall \& Borg, 2012) menjelaskan bahwa validitas isi ini jenisnya validitas yang dianalisis melalui pengujian terhadap isi alat ukur yang dapat dianalisa secara wajar, yaitu sejauh mana unsur-unsur alat ukur tersebut mencakup seluruh luas isi benda yang akan diukur oleh alat ukur tersebut/berkaitan dengan ungkapan total daerah.

Validitas disini mengacu kepada pendapat (Setyawati et al., 2018) yang menjelaskan bahwa validitas isi terdiri dari face validity atau validitas tampilan dan logical validity atau validitas logis. Dan turunan dari validitas tersebut, maka aspek-aspek yang perlu dinilai dalam sebuah instrumen adalah kejelasan, ketepatan isi, relevansi, kevalidan isi, tidak ada bias, dan ketepatan bahasa. Sedangkan untuk mengukur kelayakan dari instrumen efektivitas, peneliti melakukan validitas logis dan validitas empiris. Hal ini seiring dengan pendapat Riyani et al (2017) yang menjelaskan bahwa validitas logis berarti penalaran. Jadi validitas logis itu mengukur kevalidan bersumber pada hasil penalaran. Kondisi valid dianggap terpenuhi karena instrumen sudah dibuat dengan bagus. Ada dua jenis validitas logis diantaranya validitas isi dan konstruk (construct validity). Sedangkan "validitas empiris" memuat kata "empiris" yang artinya "pengalaman". Jadi sebuah instrumen dikatakan valid diukur dari pengalaman, instrumen dianggap mempunyai validitas empiris apabila telah diuji dari pengalaman. Kemudian, validitas logis diuji oleh para ahli dan validitas empiris diuji ke peserta didik untuk mengetahui kevalidan, reliabel, tingkat kesukaran dan daya pembedanya. Untuk analisis data validasi instrumen validasi, instrumen kepraktisan, instrumen tes objektif, dan validasi produk, peneliti menggunakan rumus aiken. Menurut (Azwar, 2018), analisis dengan rumus aiken dilakukan dengan langkah-langkah sebagai berikut: (a) skor jawaban diberikan oleh para validator, (b) setiap skor oleh validator untuk semua indikator dijumlahkan, (c) menganalisis dengan statistika Aiken's V:

$$
V=\sum s /[n(c-1)]
$$

Dari rumus tersebut diketahui $\mathrm{V}=$ Indeks Validitas, $\mathrm{S}=\mathrm{r}-\mathrm{lo}, \mathrm{N}=$ Jumlah validator atau panel penilai, lo = Angka penilai validitas terendah (dalam hal ini $=1$ ), $\mathrm{c}=$ Angka penilaian validitas tertinggi (dalam hal ini $=5$ ), $r=$ Angka yang diberikan seorang validator. Dalam mengukur tinngkat kevalidan menurut (Azwar, 2018), rentang $V$ yang didapat akan diperoleh antara 0 sampai 1,00 . Untuk rentang $\geq 0,6$ dapat diinterprestasikan sebagai koefisien yang cukup tinggi, sehingga bisa kategori validitasnya berada pada tingkatan valid. Maka, jika didapat dari hasil validasi tersebut berada diangka 0,6 atau lebih, instrumen atau produk dikatakan valid dan jika berada dibawah 0,6, maka instrumen/ produk dikatakan tidak valid. Untuk analisis data instrumen kepraktisan, peneliti menggunakan rumus yang dikenalkan oleh (Riduwan, 2019) yaitu: 


$$
\text { Skor nilai ideal }=\frac{\text { skor yang diperoleh }}{\text { skor maksimum }} \times 100 \%
$$

Selanjutnya nilai hasil kepraktisan dikategorikan sesuai dengan kategori kepraktisan produk yang mengacu pada (Riduwan, 2019) dengan dimodifikasi. Katagori yang digunakan untuk uji Praktis di tunjukkan pada Tabel 1. Untuk analisis data tes objektif untuk uji efektivitas, peneliti menganalisis skor yang didapatkan mahasiswa ketika mengerjakan 30 soal objektif (soal-soal tersebut telah melalui proses uji validasi butir dan validitas logis). Apabila skor berada lebih sama dengan 70, maka mahasiswa dianggap tuntas dalam mengerjakan tes objektif. Untuk analisis secara keseluruhan, peneliti mengacu pada rumus yang dijelaskan oleh (Fivia Eliza et al., 2019) sehinga rumusnya menjadi:

$$
P K=\frac{J T}{J S} \times 100 \%
$$

Tabel 1. Kategori Kepraktisan Produk

\begin{tabular}{clll}
\hline No & Tingkat Pencapaian (\%) & Kategori \\
\hline 1 & $(61-100) \%$ & Praktis & \\
5 & $(0-60) \%$ & Tidak Praktis & \\
\hline & & & Sumber: (Riduwan, 2019)
\end{tabular}

Kemudian, efektivitas pada penelitian ini juga ditinjau dari ketuntasan klasikal mahasiswa dalam satu kelas. Hal ini Merujuk kepada (Listari et al., 2020) yang menyatakan "ketuntasan klasikal atau presentase kelulusan peserta didik yang harus dipenuhi adalah 80\%". Jadi dalam hal ini e-learning dikatakan efektif jika tingkat kelulusan mahasiswa sama atau lebih dari 80\%. Efektivitas pada penelitian ini juga ditinjau dari aspek Gain Score, yang mana Richard R Hake dalam (Istiqamah, 2019; Hartati Susanto, 2020) menjelaskan Gain Score ini adalah membandingkan nilai pre-test dengan post-test. Sehingga dalam menganalisis peningkatan hasil belajar dari pretest dan posttest saat memakai skor N-Gain sebagai berikut:

$$
N-\text { Gain }=\frac{\text { Spost-Spre }}{\text { Smaks-Spre }} \times 100
$$

Pada rumus tersebut, Spost berarti skor posttest, Spre berarti skor pretest, dan Smaks berarti Skor maksimum ideal. Untuk kategori Gain Score menurut Hake Ricard R dalam (Ikram et al., 2021) di tunjukkan pada Table 2. Setelah penghitungan dalam mengukur peningkatan hasil belajar mahasiswa dengan mengggunakan rumus Gain Score. E-learning yang dikembangkan dapat dikatakan efektif apabila nilai Gain Score minimal pada kategori sedang.

Tabel 2. Kategori Gain Score

\begin{tabular}{clc}
\hline No & Gain score & Kategori \\
\hline 1. & N- gain $>70$ & Tinggi \\
2. & $30 \leq \mathrm{N}-$ gain $\leq 70$ & Sedang \\
3. & N-gain $<30$ & Rendah \\
\hline
\end{tabular}

Sumber: Hake Ricard R dalam (Ikram et al., 2021)

\section{HASIL DAN PEMBAHASAN}

\section{Hasil}

Tahap dianalisis, pada penelitian ini yang menjadi potensinya adalah mahasiswa di UNP, karena mahasiswa sebagai peserta didik jika diasah terus potensi dan keterampilan melalui pengembangan akan mendapatkan hasil yang maksimal. Potensi selanjutnya adalah ICT yang semakin berkembang yang mengakibatkan pembelajaran mahasiswa dikelas akan dipermudah. Kemudian, yang menjadi masalahnya adalah mahasiswa sebagai peserta didik dan dosen sebagai pendidik pada perkuliahan Bahasa Pemprograman yang sewaktu menggunakan e-learning UNP banyak dihadapi berbagai kendala, seperti teknis, di mana mahasiswa susah mengakses E-Learning, apalagi pada jam-jam sibuk dan e-learning seringkali mengalami error ketika diakses. Sehingga pembelajaran tidak optimal dan tidak berjalan dengan baik. Tahap mengumpulkan informasi. Dari informasi yang telah terkumpul disimpulkan perkuliahan Bahasa Pemprograman yang menggunakan e-learning UNP banyak dihadapi berbagai kendala oleh dosen dan mahasiswa. Seperti susahnya e-learning tersebut diakses pada jam-jam sibuk, sering error, 
serta terdapatnya beberapa perbedaan tampilan di laptop dan smartphone. Dan dari hasil identifikasi kebutuhan, dibutuhkan alternatif media pembelajaran dalam mata kuliah Bahasa Pembelajaran di UNP.

Tahap membuat desan produk, peneliti memulai dengan melakukan perencanan awal, merancang desain, menyiapkan peralatan/ bahan, dan mengaktifkan e-learning. E-learning tersebut dibuat dengan berbagai fitur, diantaranya: a.) Tab "About" berisi tentang Rencana Pembelajaran Semester (RPS), Arahan Pembelajaran yang menjadi informasi penting untuk memulai perkuliahan disetiap pertemuannya, Petunjuk Penggunaan E-Learning dan Profil mahasiswa; b.) Tab "Messages" adalah tempat mahasiswa menerima umpan balik/ feedback dari setiap tugas yang dikerjakan. Disini nilai-nilai tugas setiap pertemuan dan pengayaan akan diinformasikan; c.) Tab "Kuliah" adalah tempat mahasiswa melaksanakan pembelajaran dari pertemuan 1 sampai 16; d.) Tab "Forum" adalah tempat mahasiswa berdiskusi pada setiap pertemuan perkuliahan; e.) Tab "Partisipan" adalah tempat mahasiswa dan dosen melihat partispasi yang sedang online dan daftar partisipan perkuliahan; f.) Tab "Kontak" berisi tentang informasi dan kontak pengembang e-learning; g.) Tab "Tanya" adalah tempat mahasiswa bertanya tentang masalah seputar penggunaan e-learning; h.) Tab "Sosial" merupakan wadah untuk berkomunikasi dengan dosen dan sesama mahasiswa terkait perkuliahan. Disini adalah media sosial mahasiswa dengan dosen. Disini dosen akan update informasi perkuliahan. Setiap postingan dan komentar akan masuk ke notifikasi mahasiswa. Disini dosen juga akan memberikan kuis dan lainnya; i.) Tab "Library" berisi sumber pembelajaran pendukung (literatur/ referensi) terkait perkuliahan; j.) Tab "Labor" adalah Laboratorium Pemprograman Bahasa C, disini mahasiswa dapat membuat program Bahasa C dan menjalankannya; k.) Icon "Gerigi" yang berada pada bagian atas sebelah kanan adalah tempat mahasiswa mengedit profil dan melihat akun dan juga logout; 1.) Icon "Lonceng" yang berada pada bagian bawah sebelah kanan adalah tempat mahasiswa menerima notifikasi seputar e-learning. Tampilan e-learning yang dibuat dapat dilihat pada Gambar 1, 2, 3 dan 4 .

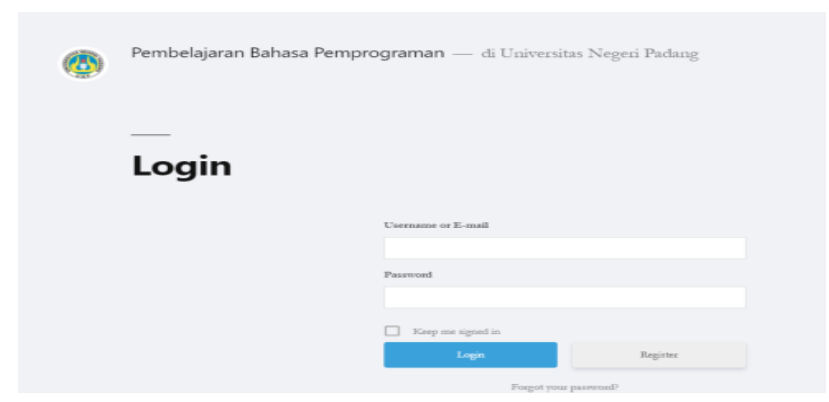

Gambar 1. Halaman Login dari E-learning

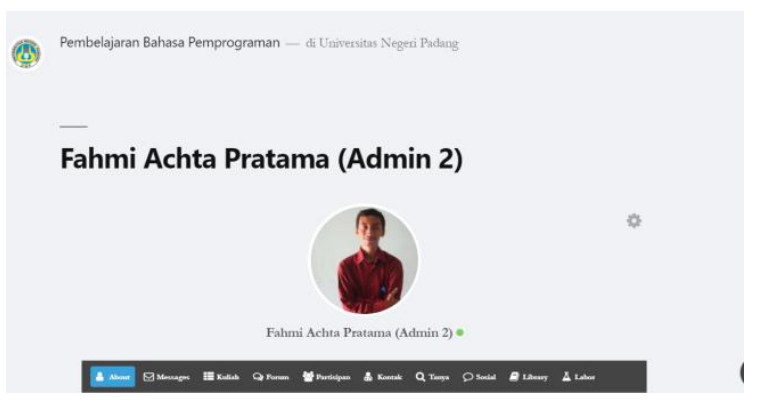

Gambar 2. Tampilan Bagian Atas E-Learning

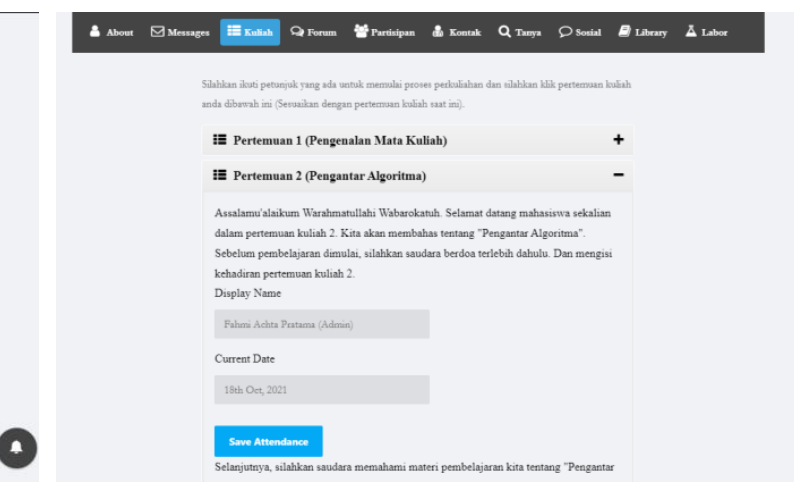

Gambar 4. Tampilan Perkuliahan Pada $E$ Learning

Tahap memvalidasi desain, peneliti memulai dengan validasi instrumen validitas oleh 2 orang ahli instrumen, dan memperoleh nilai 0,76136 dengan kategori valid. Kemudian, setelah instrumen validasi valid, peneliti melakukan validasi produk. Dari hasil validasi produk yang dilakukan, dari 2 orang ahli media, produk yang dikembangkan mendapat nilai 0,902 dengan kategori valid dan dari 2 orang ahli materi Bahasa Pemprograman mendapat nilai 0,842 dengan kategori valid. Setelah, produk dikatakan valid, maka tahap selanjutnya peneliti melakukan beberepa perbaikan produk berdasarkan saran-saran dari validator, yaitu perbaikan penempatan menu petunjuk penggunaan e-learning dan beberapa perubahan lainnya. 
Tahap uji coba terbatas, peneliti memulai penelitian dengan memvalidasi instrumen kepraktisan dengan dua orang ahli instrumen dan mendapatkan nilai 0,841 dengan kategori valid. Setelah dikatakan valid, selanjutnya peneliti melakukan uji coba kepada dua orang dosen Bahasa Pemprograman untuk dilihat kepraktisannya. Dosen 1 mendapatkan nilai 95\% dan dosen 2 mendapat nilai 80,25\%, sehingga diketahui secara keseluruhan produk yang dikembangkan mendapat kategori praktis dengan nilai rata-rata $88,75 \%$. Selanjutnya masih pada uji coba terbatas, peneliti melakukan uji coba e-learning pada 5 orang mahasiswa dalam kelompok kecil diluar sampel penelitian pada uji coba pemakaian. Dari hasil uji coba pada mahasiswa tersebut, e-learning mendapat nilai $80 \%$ dengan kategori praktis. Kemudian, Pada tahap selanjutnya, tahap revisi produk, peneliti melakukan perbaikan produk berdasarkan saran dan masukan para responden di uji coba terbatas. Peneliti memperbaiki bagian absensi dengan menambah keterangan lebih lengkap pada bagian tersebut. Setelah revisi produk, peneliti melakukan uji coba pemakaian selama 7 hari (pretest, pembelajaran dengan 6 topik dan posttest). Dari hasil analisis kepraktisan produk oleh 30 orang mahasiswa sebagai pengguna pada uji coba pemakaian diketahui bahwa e-learning berbasis wordpress yang peneliti kembangkan mendapatkan skor rata-rata 82,83\% dan mendapat kategori "Praktis".

Selanjutnya, masih dalam uji coba pemakaian peneliti melakukan uji efektivitas. Uji efektivitas dimulai dari melakukan uji validitas butir soal dan validitas logis tes objektif oleh dua orang ahli materi Bahasa Pemprograman. Dari hasil analisis uji validasi instrumen tes objektif diketahui bahwa rata-rata penilaian oleh dua orang ahli instrumen secara keseluruhan terhadap instrumen validitas produk adalah 0,83 dan mendapat kategori "Valid". Setelah dikatakan valid, selanjutnya masih pada uji coba pemakaian, diketahui bahwa dari 30 orang mahasiswa pada saat pretest atau sebelum perlakuan digunakannya $e$ learning berbasis wordpress sebagai media pembelajaran hanya 8 orang yang tuntas sehingga presentase ketuntasan adalah 27\% dengan kategori tidak efektif. Sedangkan setelah diberi perlakuan berupa digunakannya e-learning berbasis wordpress sebagai media pembelajaran, pada saat postest dari 30 orang mahasiswa tersebut diketahui 26 orang mahasiswa yang tuntas dengan kategori efektif. Sehingga berdasarkan ketuntasan klasikal dapat disimpulkan digunakannya e-learning berbasis wordpress efektif digunakan sebagai media pembelajaran Bahasa Pemprograman. Hasil analisis Uji efektivitas dijabarakan pada Tabel 3. Setelah analisis berdasarkan ketuntasan klasikal, selanjutnya peneliti menganalisis berdasarkan Gain Score dari 30 orang mahasiswa yang mengikuti uji coba pemakaian dimulai dari pretest dan postest. Dari analisis yang dilakukan dengan Gain Score. Maka didapatkan nilai minimum 23,33, nilai maksimum 89,55, sehingga $N$-Gain Score (\%) mendapat nilai 54,25 dengan kategori sedang. Maka disimpulkan e-learning berbasis wordpress efektif digunakan sebagai media pembelajaran Bahasa Pemprograman.

Tabel 3. Hasil Analisis Uji Efektivitas Berdasarkan Ketuntasan Klasikal

\begin{tabular}{lcc}
\hline Keterangan & Pretest & Postest \\
\hline Jumlah Mahasiswa Yang Mengikuti & 30 & 30 \\
Jumlah Mahasiswa Yang Tuntas & 8 & 26 \\
Jumlah Mahasiswa Yang Tidak Tuntas & 22 & 4 \\
Persentase Ketuntasan (\%) & 27 & 86,67 \\
\hline Kategori & Tidak Efektif & Efektif \\
\hline
\end{tabular}

\section{Pembahasan}

Penelitian pengembangan yang telah dilakukan bertujuan menghasilkan produk berupa media pembelajaran yang bisa diakui dan dipertanggungjawabkan, karena media yang dikembangkan telah divalidasi oleh para pakar. Validasi produk dapat dilakukan dengan menghadirkan beberapa pakar yang berpengalaman untuk menilai produk baru telah yang dirancang (Sugiyono, 2017). Produk yang dihasilkan oleh peneliti telah melewati penilaian, uji coba dan penyempurnaan yang berulang kali. Hasil validasi oleh 4 orang validator terhadap e-learning berbasis wordrpess menyatakan bahwa e-learning valid digunakan sebagai media pembelajaran. Penilaian validitas ini dilihat dari segi isi dan tujuan, instruksional dan teknis. Tiga kriteria utama dalam penilaian media pembelajaran, diantaranya kualitas isi dan tujuan, kualitas instruksional, dan kualitas teknis (Arsyad, 2017). Sedangkan untuk kepraktisan, pada uji coba terbatas yang diujikan pada mahasiswa dan dosen, e-learning berada pada kategori praktis. Dosen merespon bahwa e-learning mudah dan praktis digunakan dalam pembelajaran. Kepraktisan bermakna kemudahan saat mempersiapkan, melakukan pengolahan dan menterjemahkan serta administrasi, apalagi khususnya dalam pembelajaran, media pembelajaran mesti mudah digunakan pengguna(Irsalina \& Dwiningsih, 2018; Muslimah et al., 2019). Mengukur tingkat kepraktisan dapat dilihat dari pertimbangan para dosen sebagai pendidik dan mahasiswa sebagai peserta didik (Aufa et al., 2021; Yanto, 2019). 
Pertimbangan mereka didapatkan sebagai pengguna media yang dikembangkan. Dalam pertimbangan tersebut mereka mempertimbangkan kemudahan dan kegunaan dari e-learning yang dikembangkan. Uji efektivitas dapat dilihat dari keberhasilan proses belajar di indikasikan dengan keberhasilan mahasiswa menguasai materi yang diberikan. Dari hasil analisis e-learning berbasis wordrpess dikembangkan efektif digunakan dalam pembelajaran karena e-learning mencapai tujuan pembelajaran. efektif adalah hasil yang didapat sama seperti tujuan yang sudah ditentukan(Kurniasari et al., 2017; Sulthon, 2017). Artinya Setelah melewati tahap-tahap pada penelitian dan setelah di uji coba serta revisi, e-learning dikatakan valid, praktis, dan efektif. Jadi, e-learning berbasis wordrpess yang dibangun, layak digunakan untuk alternatif media pembelajaran pada mata kuliah Bahasa Pemprograman. tiga aspek yang perlu diperhatikan dalam menilai kualitas suatu produk dari penelitian pengembangan, yaitu validitas, kepraktisan, dan efektivitas (Dwijayani, 2017; Zakiamani et al., 2020).

Adapun kelebihan produk yang dikembangkan dalam penelitian ini adalah e-learning dibuat dengan desain yang lebih simpel, ringan dan mudah diakses, dan juga penerapannya bisa dilakukan secara full atau blended learning. Di dalam e-learning ini mahasiswa juga dapat melakukan praktikum secara langsung, karena disini mereka bisa membuat program dan mensimulasikannya. Dari hasil penelitian pengembangan ini, maka produk yang dibuat mampu memberikan inovasi baru dalam dunia pendidikan ataupun memberikan solusi terhadap permasalahan yang ada, khususnya pada pembelajaran Bahasa Pemprograman di UNP. E-learning berbasis wordpress pada pembelajaran Bahasa Pemprograman ini berimplikasi pada mahasiswa atau dosen untuk mengubah pola pengajaran sesuai kurikulum saat ini dan tujuan pendidikan nasional, yakni pengajaran harus dapat dilaksanakan dengan menarik salah satunya menggunakan media dalam proses pembelajaran. Implikasi dari pengembangan e-learning berbasis wordpress adalah meningkatkan keefektifan mahasiswa ketika memahami materi dengan mandiri, kreatif, dan menyenangkan dimanapun dan kapanpun terbatas ruang dan waktu. Hal lainnya yaitu memberikan kesempatan kepada mahasiswa untuk belajar mandiri dan aktif mencari pengetahuan terhadap materi pelajaran sesuai dengan tujuan pembelajaran Bahasa Pemprograman. Keterbatasan dalam penelitian ini adalah produk yang dihasilkan berupa media e-learning berbasis wordpress. Kemudian uji validasi dilakukan pada validasi ahli dan validasi empiris (uji coba lapangan) dan uji coba pemakaian dilakukan di UNP dalam pembelajaran Bahasa Pemprograman. Kemudian, untuk peneliti selanjutnya, peneliti mempunyai saran agar menganalisis dan menyempurnakan kembali e-learning berbasis wordpress sesuai dengan perkembangan teknologi yang ada dimasa mendatang.

\section{SIMPULAN}

Berdasarkan hasil penelitian, e-learning berbasis wordpress yang telah peneliti kembangkan layak digunakan dalam pembelajaran. Kemudian mendapatkan respon positif dari dosen dan mahasiswa sehingga praktis dalam penggunaannya. Serta, e-learning berbasis wordpress ini efektif sehingga dapat meningkatkan hasil belajar mahasiswa pada pembelajaran Bahasa Pemprograman di UNP.

\section{DAFTAR PUSTAKA}

Abdulmajid, N. W., Pramuntadi, A., Riyanto, A. B., \& Rochmah, E. (2017). Penerapan E-Learning Sebagai Pendukung Adaptive Learning dan Peningkatan Kompetensi Siwa SMK di Kabupaten Bantul. Jurnal Taman Vokasi, 5(2), 170-182. https://doi.org/10.30738/jtv.v5i2.2475.

Anggrasari, L. A. (2020). Penerapan e-learning untuk meningkatkan kemampuan literasi digital di era new normal. Premiere Educandum: Jurnal Pendidikan Dasar Dan Pembelajaran, 10(2), 248. https://doi.org/10.25273/pe.v10i2.7493.

Arsyad, A. (2017). Media Pembelajaran Edisi Revisi. PT Raja Grafindo Persada.

Aufa, N., Zubainur, C. M., \& Munzir, S. (2021). Pengembangan Perangkat Pembelajaran Model Missouri Mathematics Project (MMP) Berbantuan Software Geogebra untuk Meningkatkan Pemahaman Konsep Siswa. Jurnal Inovasi Penelitian, 1(11), 2377-2394. https://doi.org/10.47492/jip.v1i11.

Azizah, A. (2020). Pelatihan Pembelajaran Daring Dimasa Pandemi Covid-19 Untuk Guru- Guru Sd Negeri 3 Melayu Muara Teweh Online Learning Training During the Covid 19 Pandemic for Teachers Sd Negeri 3 Malay Muara Teweh. BAKTI BANUA : Jurnal Pengabdian Kepada Masyarakat, 1(2), 78-83. https://ejurnal.stimi-bjm.ac.id/index.php/BBJM/.

Azwar, Saifuddin. (2018). Reliabilitas dan Validitas Edisi 4. Pustaka Belajar.

Bani Hani, A., Hijazein, Y., Hadadin, H., Jarkas, A. K., Al-Tamimi, Z., Amarin, M., Shatarat, A., Abu Abeeleh, M., \& Al-Taher, R. (2021). E-Learning during COVID-19 pandemic; Turning a crisis into opportunity: A cross-sectional study at The University of Jordan. Annals of Medicine and Surgery, 70(September), 102882. https://doi.org/10.1016/j.amsu.2021.102882. 
Budi, S. P., Suprapti, Danang, \& Febryantahanuji. (2019). Media Pembelajaran E-Learning Dengan Metode Parsing Untuk Meningkatkan Efektifitas Pembelajaran di Sekolah Berbasis Web. Jurnal Ilmiah Sistem Informasi, Teknologi Informasi Dan Sistem Komputer, 14(2), 105-115. https://doi.org/10.33998/processor.2019.14.2.644.

Cyly Arrum Dalu, Z., \& Rohman, M. (2019). Pengembangan E-Learning Sebagai Media Pembelajaran Simulasi dan Komunikasi Digital bagi Siswa SMK. Jupiter (Jurnal Pendidikan Teknik Elektro), 04(1), 25-33. https://doi.org/10.25273/jupiter.v4i1.4132.

Dian Ari Widyastuti. (2017). Evaluasi Layanan Bimbingan Kelompok di Sekolah Menengah Pertama Berdasarkan Model Kesenjangan (Dispcrepancy Model). Junal Konseling Gusjigang. https://doi.org/10.24176/jkg.v3i1.1603.

Dwijayani, N. M. (2017). Pengembangan Media Pembelajaran ICARE. Kreano, Jurnal Matematika KreatifInovatif, 8(2), 126-132. https://doi.org/10.15294/kreano.v8i2.10014.

Elyas, A. H. (2018). Penggunaan model pembelajaran e-learning dalam meningkatkan kualitas pembelajaran. Jurnal Warta, 56(04), http://jurnal.dharmawangsa.ac.id/index.php/juwarta/article/view/4.

Fivia Eliza, Pranata, N., \& Fadli, R. (2019). Multimedia Interaktif Berbasis Course Lab Dalam Pembelajaran Memahami Dasar-Dasar Elektronika. Jurnal Teknologi Informasi Dan Pendidikan, 12(1), 1-7. https://doi.org/10.24036/tip.v12i1.

Gall, M., Gall, J. P., \& Borg, W. R. (2012). Applying Educational Research. Pearson.

Hanifah Salsabila, U., Irna Sari, L., Haibati Lathif, K., Puji Lestari, A., \& Ayuning, A. (2020). Peran Teknologi Dalam Pembelajaran Di Masa Pandemi Covid-19. Al-Mutharahah: Jurnal Penelitian Dan Kajian Sosial Keagamaan, 17(2), 188-198. https://doi.org/10.46781/al-mutharahah.v17i2.138.

Hartati Susanto, P. S. (2020). Peran Pemuda Tani Dalam Pencegahan Penyebaran Covid-19 Di Tingkat Petani (Kasus Di Kabupaten Magelang). BASKARA : Journal of Business \& Entrepreneurship, Vol 2, No 2 (2020): Baskara: Journal of Business and Entrepreneurship, 107-112. https://doi.org/10.24853/baskara.2.2.107-112.

Ihsan, M. S., Ramdani, A., \& Hadisaputra, S. (2019). Pengembangan E-Learning Pada Pembelajaran Kimia Untuk Meningkatkan Kemampuan Berpikir Kritis Peserta Didik. J. Pijar MIPA, 14(2), 84-87. https://doi.org/10.29303/jpm.v14i2.1238.

Ikram, A. F. Z., Elvia, R., \& Handayani, D. (2021). Pengaruh Pemanfaatan Media Presentasi Online Prezi Pada Materi Konsep Mol Terhadap Hasil Belajar Siswa (Studi Eksperimen di Kelas X MIPA SMAN 9 Bengkulu Utara). Alotrop, 5(1), 64-73. https://doi.org/10.33369/atp.v5i1.16488.

Irsalina, A., \& Dwiningsih, K. (2018). Practicality Analysis of Developing the Student Worksheet Oriented Blended Learning in Acid Base Material. JKPK (Jurnal Kimia Dan Pendidikan Kimia), 3(3), 171. https://doi.org/10.20961/jkpk.v3i3.25648.

Istiqamah. (2019). Pembelajaran Menulis Karangan Deskripsi Dengan Model Kooperatif Tipe Stad. Journal of Chemical Information and Modeling, 53(9), 1689-1699. https://doi.org/10.22373/jid.v19i2.5034.

Karollina, N., Hidayati, U., \& Syaflita, D. (2021). Penggunaan Aplikasi Google Classroom Dan Google Form Pada Pembelajaran Ipa Di Mts Darul Hikmah Pekanbaru. Riau Education Journal, 1(1), 21-27. https://jurnal.pgririau.or.id/index.php/rej/article/view/8.

Khusniyah, T. W. (2020). Efektivitas E-Learning Terhadap Hasil Belajar Mahasiswa Pada Mata Kuliah Konsep Dasar IPS. SAP (Susunan Artikel Pendidikan), 4(3). https://doi.org/10.30998/sap.v4i3.6283.

Kurniasari, D., Kurniasari, D., \& Marta, M. S. (2017). Pengaruh Anggaran Berbasis Kinerja Terhadap Efektivitas Pengendalian Anggaran Di Dinas Pendapatan dan Pengelolaan Keuangan dan Aset Kabupaten Bandung Barat. Jurnal Ilmu Administrasi Publik, 53(4), 130. https://doi.org/10.26905/pjiap.v2i2.1446.

Lilis, A., Ulfah, S. I., \& Endang, D. R. (2020). Efektivitas Penggunaan E-Learning Sebagai Media Pembelajaran Saat Pandemi Covid 19. JKBM (Jurnal Konsep Bisnis Dan Manajemen), 7(November), 72-81. https://doi.org/10.31289/jkbm.v7i1.4333.

Listari, A. W., Mangesa, R. T., \& Muliadi. (2020). Penerapan Tutor Sebaya Dalam Implementasi Strategi CIRC Berbasis Active Learning Untuk Meningkatkan Hasil Belajar Siswa Pada Mata Pelajaran Sistem Komputer di SMKN 5 Makassar. Jurnal MediaTIK, 3(3), 13. https://doi.org/10.26858/jmtik.v3i3.15174.

Muharto, M., Hasan, S., \& Ambarita, A. (2017). Penggunaan Model E-Learning Dalam Meningkatkan Hasil Belajar Mahasiswa Pada Materi Microprocessor. IJIS-Indonesia Journal on Information System, 2(April). https://doi.org/10.36549/ijis.v2i1.26.

Muliono, R. (2016). Optimasi Website Berbasis Cms Pada Google Pegespeed. CESSJournal Of Computer 
Engineering, System And Science, 1(2), 32-35. https://doi.org/10.24114/cess.v1i2.4065.

Muslimah, S. L., Rosalina, E., \& Febriand, R. (2019). Pengembangan LKS Tematik berbasis Outdoor Learning pada siswa Sekolah Dasar. Jurnal Basicedu, 1(1), 1-9. https://doi.org/10.31004/basicedu.v5i4.1069 ISSN.

Ningsih, S. R., \& Erdisna. (2021). Implementasi E-Learning Sebagai Media Pembelajaran Online Bagi Siswa Sekolah Menengah Kejuruan ( SMK ). JOISIE Journal of Information System And Informatics Engineering, 5(1), 20-28. https://doi.org/10.35145/joisie.v5i1.1307.

Prasetya, M. A. (2015). E-Learning Sebagai Sebuah Inovasi Metode Active Learning. Edukasia: Jurnal Penelitian Pendidikan Islam, 10(2), 319-338. https://doi.org/10.21043/edukasia.v10i2.797.

Radhiani, A., \& Sirwan. (2019). Pemanfaatan E-Learning Berbasis Wordpress Untuk Meningkatkan Hasil Belajar Siswa. Jurnal MediaTIK, 2(1), 1-7. https://doi.org/10.26858/jmtik.v2i1.9822.

Ratnawati, N. K. M., Utama, I. B., \& Dewantara, I. P. M. (2019). Pemanfaatan E-Learning Pada Mata Pelajaran Bahasa Indonesia. Jurnal Pendidikan Bahasa Dan Sastra Indonesia Undiksha, 9(1), 46-56. https://doi.org/10.23887/jjpbs.v9i1.20300.

Riduwan. (2019). Belajar Mudah Penelitian untuk Guru-Karyawan dan Peneliti Pemula. Alfabeta.

Rijal, A., \& Sofiarini, A. (2019). Pengembangan E-Learning Mata Kuliah Pembelajaran Matematika Sd Berbasis Aplikasi Moodle Di Pgsd. Jurnal Basicedu, 3(4), 2071-2082. https://doi.org/10.31004/basicedu.v3i4.266.

Riyani, R., Maizora, S., \& Hanifah, H. (2017). Uji Validitas Pengembangan Tes Untuk Mengukur Kemampuan Pemahaman Relasional Pada Materi Persamaan Kuadrat Siswa Kelas Viii Smp. Jurnal Penelitian Pembelajaran Matematika Sekolah (JP2MS), 1(1), 60-65. https://doi.org/10.33369/jp2ms.1.1.60-65.

Sakiah, N. A., \& Effendi, K. N. S. (2021). Analisis Kebutuhan Multimedia Interaktif Berbasis PowerPoint Materi Aljabar Pada Pembelajaran Matematika SMP. JP3M (Jurnal Penelitian Pendidikan Dan Pengajaran Matematika), 7(1), 39-48. https://doi.org/10.37058/jp3m.v7i1.2623.

Saluky, S. (2016). Pengembangan Bahan Ajar Matematika Berbasis Web Dengan Menggunakan Wordpress. Eduma: Mathematics Education Learning and Teaching, 5(1), 80-90. https://doi.org/10.24235/eduma.v5i1.685.

Santosa, F. H., Negara, H. R. P., \& Samsul Bahri. (2020). Efektivitas Pembelajaran Google Classroom Terhadap Kemampuan Penalaran Matematis Siswa. Jurnal Pemikiran Dan Penelitian Pendidikan Matematika (JP3M), 3(1), 62-70. https://doi.org/10.36765/jp3m.v3i1.254.

Saputra, W. N. E. (2019). Evaluasi Model Discrepancy: Salah Satu Model Evaluasi Program Konseling. Insight Jurnal. https://doi.org/10.21009/INSIGHT.081.03.

Sari, R. M. M., \& Priatna, N. (2020). Model-Model Pembelajaran di Era Revolusi Industri 4.0 (E-Learning, MLearning, AR-Learning dan VR-Learning). Jurnal Ilmiah Fakultas Keguruan Dan Ilmu Pendidikan, 6(1), 107-115. http://ejournal.unsub.ac.id/index.php/FKIP/article/view/699/591.

Setyawati, R. D., Happy, N., \& Murtianto, Y. H. (2018). Instrumen Angket Self-Esteem Mahasiswa Ditinjau Dari Validitas Dan Reliabitas. Phenomenon: Jurnal Pendidikan MIPA, 7(2), 174-186. https://doi.org/10.21580/phen.2017.7.2.1932.

Sianturi, S. R., \& Lisum, K. (2018). Peningkatan Motivasi Belajar melalui Evaluasi E - Learning pada Institusi Keperawatan di Jakarta dan Depok. Jurnal Pendidikan Keperawatan Indonesia, 31. https://doi.org/10.17509/jpki.v4i2.11563.

Sugiyono. (2017). Metode Penelitian Kuantitatif, Kualitatif, dan R\&D. Alfabeta.

Sulthon, S. (2017). Pembelajaran IPA yang Efektif dan Menyenangkan bagi Siswa MI. ELEMENTARY: Islamic Teacher Journal, 4(1). https://doi.org/10.21043/elementary.v4i1.1969.

Universitas Negeri Padang. (2018). Buku Pedoman Akademik UNP. UNP Press.

Weni, D. M., \& Isnani, G. (2016). Meningkatkan Hasil Belajar Siswa dengan Pengembangan Media Pembelajaran E-Learning Berbasis Blog. Jurnal Pendidikan Bisnis Dan Manajemen, 2(2), 114-123. https://doi.org/2527-905X.

Widodo, A., \& Nursaptini. (2020). Problematika Pembelajaran Daring Dalam Perspektif Mahasiswa. ELSE (Elementary School Education Journal), 4, 100-115. https://doi.org/10.30651/else.v4i2.5340.

Widodo, G. S., \& Hidayah, L. (2020). Pengembangan E-Learning Mata Kuliah Profesi Keguruan Berbasis Moodle Untuk Model Blended Learning Di Universitas Islam Malang. Jurnal Bidang Pendidikan Dasar, 4(2), 114-123. https://doi.org/10.21067/jbpd.v4i2.4189.

Yanto, D. T. P. (2019). Praktikalitas Media Pembelajaran Interaktif pada Proses Pembelajaran Rangkaian Listrik. INVOTEK: Jurnal Inovasi Vokasional Dan Teknologi, 19(1), 75-82. https://doi.org/10.24036/invotek.v19i1.409.

Zakiamani, A., Zulkarnain, Z., \& Maimunah, M. (2020). Validitas dan Praktikalitas Perangkat Pembelajaran Matematika: Studi Pengembangan di SMPN Islam Teknologi Rambah. JURING Uournal for 
Research in Mathematics Learning), 3(3), 212-223. https://doi.org/10.24014/juring.v3i3.10285. Zulkarnain, A., Tirtana, A., \& Susanto, D. W. S. (2020). Sistem Informasi Karya Inovatif berbasis CMS Wordpress Studi Kasus STIKI Malang. Jurnal Ilmiah Teknologi Informasi Asia, 14(2), 93. https://doi.org/10.32815/jitika.v14i2.474. 